In his notes on Gebia pugettensis, Dana, Stimpson writes:-

"A curious parasitic bivalve, apparently new, both in genus and species, is frequently found adhering by its byssus to the inner surface of the abdomen of this crustacean. It approximates in character to the genus Lepton. Gebia pugettensis is found on the whole coast from Puget Sound to Monterey. It excavates its subterranean chambers in the sand and mud of beaches, near low-water mark, preferring that which is more or less indurated." (Stimpson, "Crustacea and Echinodermata of the Pacific Shores of North America,” Journ. Boston Soc. Nat. Hist. vol. vi. (1857), p. 48 in separate copy.)

Professor A. Milne-Edwards, on seeing my paper on Bathynectes in the 'Annals' of this month, has kindly sent me a copy of some notes published by him in 1881 , in which I find that he at that time synonymized the genus Thranites* with Bathynectes. I was unaware of the publication of this paper, which has also escaped the notice of S. I. Smith and G. O. Sars, who have since written on the genera; nor is any reference to it to be found in the 'Zoological Record.'

March 12, 1891.

\title{
Trochammina Bradyi, n. $n$.
}

Attention has been called in 'The Naturalist' of Cumbrae by Mr. Stebbing to the circumstance that the late Dr. Henry Brady, F.R.S., used the name Trochammina Robertsoni for two distinct species of Foraminifera. He first gave the name in 1876 to a delicate Carboniferous species with oblong test, bearing a remarkable though superficial resemblance to the Quinqueloculine Miliolce. Eleven years later, in 'A Synopsis of the British Recent Foraminifera,' he applied the same name to a living species not uncommon in deepish water on the west of Scotland, and known also from the south-west of Ireland. His accurate description shows that he had no intention to unite the fossil and recent forms. The latter are rather circular than oval, with the peripheral edge lobulate, and having the outermost whorl composed of from four to six somewhat inflated segments. There is no resemblance to Quinqueloculince. Since, then, the name of the recent species must be changed, I would propose to call it Trochammina Bradyi, gladly availing myself of the opportunity to pay this slight tribute of respect to my valued friend so recently lost.

David Robertson.

Fern Bank, C'umbrae, Feb. 25, 1891.

* A. Milne-Edwards, "Observations sur le genre Thranistes (Bov.)" (Bull de la Soc. Philom. de Paris, Séance du 12 mars, 1881). MilneEdwards throughout the paper per lapsum calls Bovallius's genus Thranistes instead of Thranites. 


\section{$2 \mathrm{BHL}$ Biodiversity Heritage Library}

Robertson, David. 1891. "Trochammina Bradyi, n. n." The Annals and magazine of natural history; zoology, botany, and geology 7, 388-388.

https://doi.org/10.1080/00222939109460631.

View This Item Online: https://www.biodiversitylibrary.org/item/63422

DOI: https://doi.org/10.1080/00222939109460631

Permalink: https://www.biodiversitylibrary.org/partpdf/59206

\section{Holding Institution}

University of Toronto - Gerstein Science Information Centre

\section{Sponsored by}

University of Toronto

\section{Copyright \& Reuse}

Copyright Status: NOT_IN_COPYRIGHT

This document was created from content at the Biodiversity Heritage Library, the world's largest open access digital library for biodiversity literature and archives. Visit BHL at https://www.biodiversitylibrary.org. 